\title{
Survei Pilihan Karir Ditinjau dari Profil Kepribadian DISC Pada Calon Karyawan PT. X Indonesia
}

\section{Career Choice Survey viewed by the DISC Personality Profile on Prospective Employees of PT. X Indonesia}

\author{
Dian Juliarti Bantam* \\ Program Studi Psikologi. Fakultas Ekonomi \& Sosial, Universitas Jenderal Achmad Yani Yogyakarta, Indonesia \\ Disubmit: 18 November 2020; Diproses: 19 November 2020; Diaccept: 29 November 2020; Dipublish: 01 Desember 2020 \\ *Corresponding author: E-mail: dianjb.tridharma@gmail.com
}

\begin{abstract}
Abstrak
Tujuan penelitian untuk mengidentifikasi pilihan karir dari calon karyawan di PT. X Indonesia, yang ditinjau dari pemetaan profil kepribadian. Metode penelitian ini yaitu survei dengan melibatkan 211 subjek, yang mana profil kepribadian diukur menggunakan alat tes DISC. Hasil yang diperoleh dalam penelitian menggambarkan bahwa calon karyawan PT. X Indonesia yang memiliki tipe kepribadian dominan D sebanyak 15 subjek (7,11\%), tipe kepribadian dominan I sebanyak 13 subjek (6,16\%), tipe kepribadian dominan S sebanyak 92 subjek (43,60\%) dan yang memiliki tipe keribadian dominan C sebanyak 91 subjek (43,13\%). Selain itu, hasil juga menunjukkan bahwa ada 17 pilihan karir beserta tipe yang dominan. Account Manager, Contact Center, Driver, Online Sales Officer dan Receptionist memiliki tipe dominan S. Admin, Branding and Communication Manager, Finance and Accounting, Web Developer, dan Human Resources Operations, memiliki tipe dominan C. Ada juga Bussiness Development, Graphic Designer, Office Boy, Telemarketing dan Recruitment Staff memiliki tipe dominan S dan tipe C. Sedangkan Chemist Assistant memiliki tipe dominan D dan C, serta Sales Manager dengan tipe dominan D, tipe S dan tipe C.
\end{abstract}

Kata Kunci: Pilihan Karir, Profil Kepribadian DISC

\begin{abstract}
Aim of the Study to identify the career choice of prospective employees at PT. X Indonesia, which is reviewed by the personality profile mapping. The metode of This research is a survey that involving 211 subjects, in which the personality profile is measured using the DISC test. The results showed that prospective employees of PT. X Indonesian who have dominant personality type D are 15 subjects $(7,11 \%)$, dominant personality type I are 13 subjects (6.16\%), dominant personality type $S$ are 92 subjects (43.60\%) and the last personality dominant type $C$ as many as 91 subjects (43.13\%). In addition, the results also show that there are 17 career choices and dominant personality types. Account Managers, Contact Centers, Drivers, Online Sales Officers and Receptionists have the dominant type S. Admin, Branding and Communication Manager, Finance and Accounting, Web Developers, and Human Resources Operations, have dominant type C. There are also Business Development, Graphic Designer, Office Boy, Telemarketing and Recruitment Staff have dominant type $S$ and type $C$. Meanwhile, Chemist Assistant has dominant type $D$ and $C$, and Sales Manager with dominant type $D$, type $S$ and type $C$.

Keywords: Career Choice, DISC Personality Profile
\end{abstract}

Rekomendasi mensitasi :

Bantam, D.J. 2020, Survei Pilihan Karir Ditinjau dari Profil Kepribadian DISC Pada Calon Karyawan PT. X Indonesia. Jurnal Penelitian Pendidikan, Psikologi dan Kesehatan (J-P3K), 1 (3): 269-283. 


\section{PENDAHULUAN}

Karir sebagai suatu perkembangan dan kemajuan yang diterima oleh individu sebagai hasil dari usaha yang telah dilakukan sepanjang kehidupannya. Karir menurut Arnold (Zamroni, 2016) sebagai urutan posisi yang berhubungan dengan permasalahan peran, akivitas, pekerjaan dan pengalaman yang dialami oleh individu. Artinya bahwa ada beberapa aspek karir yang objektif dimana dapat diamati dan ada aspek karir yang subjektif berdasarkan pengalaman unik atau speksifik yang dihadapi seseorang. Pengalaman karir seorang selama hidup mencerminkan perubahan kebutuhan, aspirasi, nilai-nilai, dan sikap dari pekerjaan. Hal ini dapat disebut dengan pilihan karir yang telah dilakukan oleh individu, untuk disesuaikan dengan pengalaman hidupnya.

Pilihan karir sebagai sebuah proses individu dalam membuat keputusan dan memilih pekerjaan atau aktivitas yang diinginkan. Individu yang telah menginjak remaja, merasa pilihan karir sebagai suatu hal terpenting (Jemini-Gashi \& Bërxulli, 2017). Hal ini memang menjadi konsen bagi setiap individu yang matang dari segi kognitif, emosi dan sosial. Harapannya ketika telah menempuh pendidikan yang dinginkan, maka dapat memilih karir yang sesuai. Artinya, tidak lagi menjadi seorang pengangguran ataupun bekerja dengan tingkat kepuasan yang rendah.

Begitu juga dengan perusahaan yang berharap untuk mendapatkan SDM yang potensial. Berdasarkan berita CNN Indonesia (Makkl, 2019) Badan Pusat Statistik (BPS) mendata tingkat pengangguran di Indonesia yang dapat dilihat per Februari 2019 berada pada angka 5,01\%. Angka pengangguran ini berkurang hampir 50 ribu orang dari 6,87 juta orang yang tercatat pada Februari 2018 menjadi 6,82 juta orang. Selain berkurangnya pengangguran di Indonesia, juga diharapkan dapat meningkatkan dan mengoptimalkan kualitas SDM dalam bekerja, sehingga perusahaan memperoleh pekerja yang potensial. Peningkatan kualitas SDM untuk mencapai produktivitas perusahaan dapat dicapai dengan mengelola kepuasan pekerja selama menjali aktivitasnya disebuah perusahaan.

Dalam berita CNB Indonesia Menteri Bappenas menyebutkan bahwa produktivitas tenaga kerja RI masih termasuk kategori rendah dibandingkan negara Malaysia, Thailand dan Filipina (Anggit, 2019). Menurut Vicka Yunita Tjhin, Psikolog., dalam detikHealth (Sulaeman, 2017), penurunan produktivitas salah satunya dipengaruhi oleh ketidaksesuaian minat dan potensi dengan pilihan karir ataupun pemaksaan diri dengan menjalankan pekerjaan yang berbeda passion. Oleh karena itu, pilihan karir atau pekerjaan yang tepat, diharapkan dapat meningkatkan produktivitas karyawan.

Ismail dan Nurjaya (2016) bahwa pengambilan keputusan merupakan hasil suatu proses pemilihan dari berbagai alternatif tindakan yang mungkin dipilih dengan mekanisme tertentu, dengan tujuan untuk menghasilkan keputusan yang terbaik. Pengambilan keputusan yang dimaksud terkait dengan pilihan karir dari calon karyawan dalam memilih posisi yang ditawarkan oleh PT. X Indonesia.P 
Pemilihan karir yang tepat merupakan bagian dari pengambilan keputusan yang tepat atas diri individu itu sendiri. Menurut (Alkhelil, 2016) pilihan karir merupakan proses perkembangan yang penting sepanjang kehidupan manusia, yang tidak hanya melibatkan satu keputusan tetapi serangkaian keputusan untuk bisa menetapkan pilhan terbaik dari tindakan untuk menghasilkan kemajuan. Selain itu, menurutnya pilihan karir juga ditentukan oleh matangnya sebuah perencanaan karir sebelum menentukan pilihan. Dalam bidang pekerjaan, perencanaan karir yang tepat harus disesuaikan antara persyaratan jabatan, minat dan kepribadian dari calon pekerja. Selain itu, potensi yang sesuai dengan bidang pekerjaan juga menjadi syarat perusahaan dalam mengambil keputusan saat seleksi pekerjaan.

Menurut Holland (Alkhelil, 2016), individu yang berkarir sesuai dengan kecenderungan profil kepribadian yang dimiliki, akan nyaman beraktivitas atau bekerja di lingkungannya. Holland juga meyakini bahwa pemilihan pekerjaan merupakan ekspansi kepribadian dan usaha untuk mengungkapkan diri di dunia pekerjaan. Baharuddin (Goni et al., 2016) mengatakan kepribadian terbentuk, dipertahankan, dan mengalami perubahan selama proses sosialisasi yang dilakukan berlangsung. Artinya, dengan mengetahui profil kepribadian seseorang, maka perusahaan dapat memprediksi kinerja individu kelak, karena pengalaman yang dimiliki dimasa lalu.

Diperkuat oleh Sukardi (Savitri \& Muis, 2014) bahwa pemilihan karir adalah suatu tindakan ekspresif yang memproyeksikan motivasi, pengetahuan, kepribadian dan kemampuan individu. Sejalan dengan penelitian yang dilakukan oleh Jemini-Gashi dan Bërxulli (2017) bahwa pilihan karir sejalan atau berhubungan positif dengan kepribadian seseorang. Artinya, memang pilihan karir yang dilakukan oleh seseorang, sangat berpengaruh dari kepribadian yang sudah terbentuk, meskipun jika calon karyawan memiliki pribadi yang fleksibel, ia akan mudah menyesuaikan diri. Namun, ada ciri khas yang dimiliki dari dirinya tersebut. Hal inilah yang membuat PT. X Indonesia, menggunakan tes kepribadian sebagai salah satu pertimbangan dalam membuat keputusan seleksi dari pekerjaan yang dilamar oleh calon karyawan. Tes kepribadian yang digunakan yaitu DISC (Dominance, Influence, Steadiness, dan Compliance).

PT. X Indonesia merupakan perusahaan penyedia jasa rekrutmen dan seleksi yang berbasis di Indonesia. Layanan yang ditawarkan yaitu online test psychology, Prescreening Interview, Candidate Sourcing dan sebagainya. Berdasarkan wawancara yang dilakukan Head Chief Operations Officer diketahui bahwa, alasan penggunaan DISC untuk alat tes dalam melihat kecenderungan profil kepribadian, dikarenakan DISC sebagai alat tes yang simpel dan cukup menggambarkan profil calon karyawan. DISC juga tidak menggunakan waktu yang lama dalam proses pengerjaan tes. Selain itu, sudah adanya online test yang memberikan hasil lebih cepat.

Menurut Yanuari (Goni et al., 2016), teori DISC dikemukakan oleh seorang ahli psikolog asal Amerika yang bernama William Moulton Marston pada tahun 1928 dalam bukunya yang berjudul 
Emotions of Normal People. Hanya saja, instrumen tes DISC dibuat pertama kali oleh Walter Clarke pada tahun 1956 dan terus dikembangkan oleh beberapa peneliti sejak saat itu. Marston menyatakan bahwa ekspresi dari sebuah perilaku emosi dapat dikategorikan menjadi 4 tipe perilaku saat berinteraksi dengan lingkungannya yaitu Dominance (D), Influence (I), Steadiness (S), dan Compliance (C). Tipe perilaku atau Profil kepribadian DISC dalam penelitian ini adalah profil kepribadian seseorang dalam perilaku kerja. Individu dapat dikatakan memiliki profil kepribadian tertentu apabila memiliki skor tertinggi pada salah satu kategori dari keempat kategori DISC, yaitu Dominance, Influence, Steadiness, atau Compliance.

Masing-masing profil kepribadian tersebut memiliki ciri-ciri yang berbeda antara satu dengan lainnya. Berdasarkan laporan online dari lembaga Viatech Global (2015) terkait DISC Career Management, diketahui bahwa sekiranya ada 4 ciri khas individu berdasarkan profil kepribadian dalam DISC. Dalam diri setiap individu, tidak hanya terdapat satu profil kepribadian, pastinya akan memiliki kombinasi dari dua atau lebih profil kepribadian tersebut. Namun, di antara kombinasi tersebut akan ditemui satu profil atau gaya kepribadian yang mendominasi individu, sehingga akan tampak lebih menonjol. Selain itu, dalam Profil DISC terdapat 3 grafik yang dapat dilihat pada gambar 1, 2 dan 3 (Oasis Developing Center, 2014).

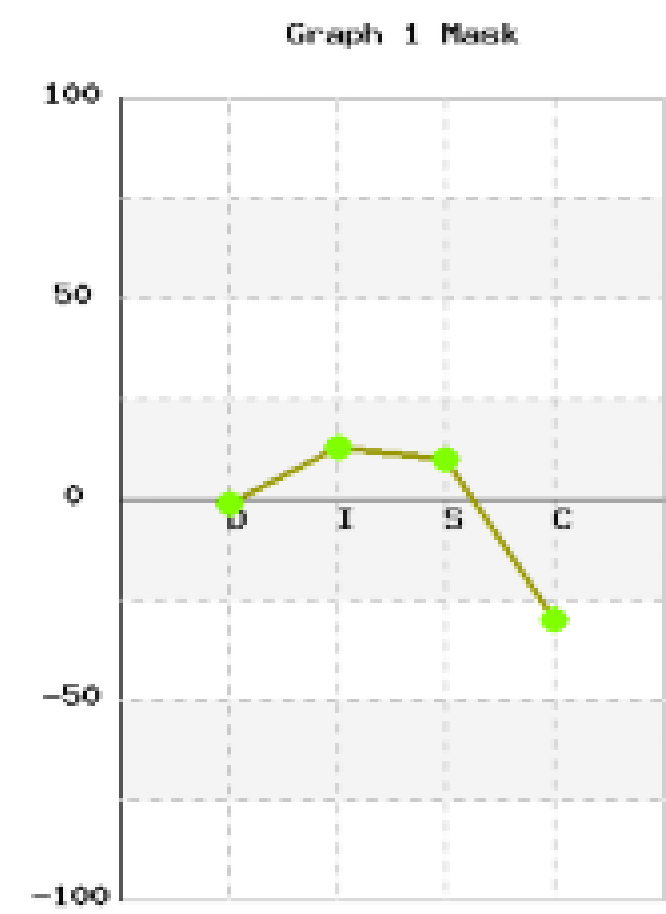

Gambar 1. Grafik 1 Mask

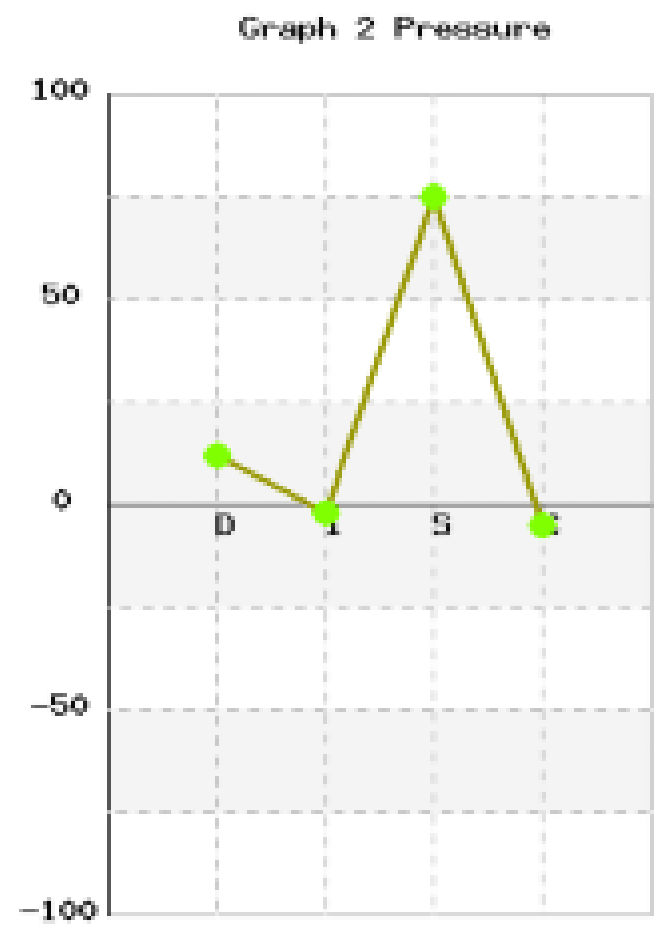

Gambar 2. Grafik 2 Pressure 


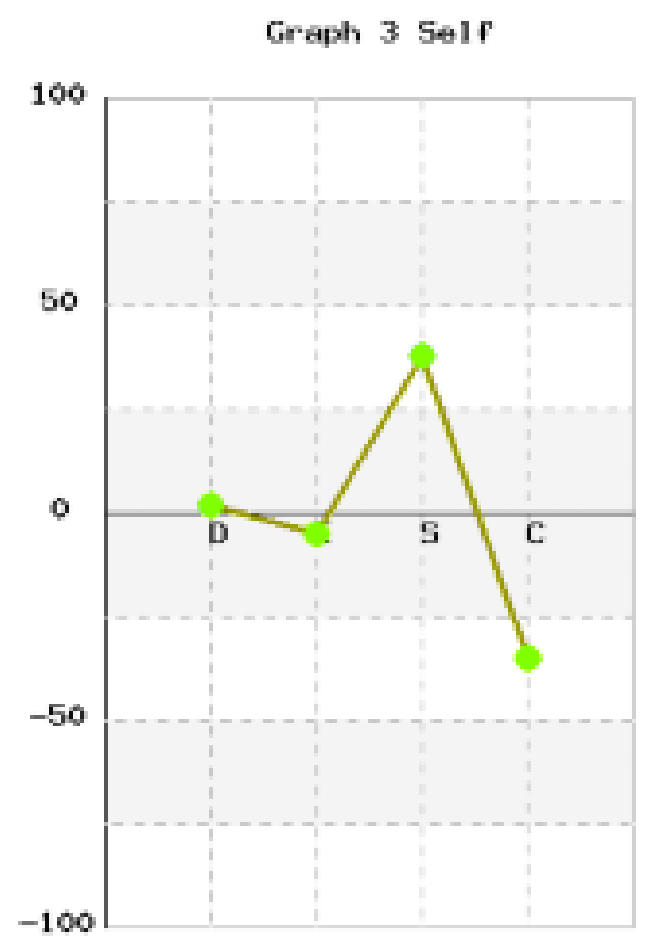

Gambar 3. Grafik 3 Self

Berikut penjelasan dari 3 grafik yang dimaksud:

1. Grafik 1 (Mask), menggambarkan kecenderungan perilaku individu yang ingin ditampilkan pada orang lain atau pada situasi tertentu, seperti dalam lingkungan pekerjaan. Ekspresi perilaku dalam grafik satu memiliki kecenderungan berubah-ubah sesuai dengan yang ingin ditampilkan agar dapat diterima dalam sebuah lingkungan. Grafik 1 bersifat public persona, yang berarti cenderung mudah untuk dimodifikasi.

2. Grafik 2 (Pressure), menampilkan kecenderungan perilaku individu dari reaksi perilaku terhadap situasi yang penuh ketegangan dan tekanan. Ekspresi tersebut mencerminkan kecenderungan dari respons otomatis individu yang terekam dalam pikiran. Grafik 2 merupakan reaksi alamiah (sub-conscious), sehingga cenderung paling sulit diubah.

3. Grafik 3 (Self), menampilkan kecenderungan perilaku seseorang dalam kebanyakan waktu yang menggambarkan bagaimana individu melihat dirinya sendiri. Dapat dikatakan, suatu perilaku sebenarnya yang mencerminkan siapa diri individu tersebut. Grafik 3 lebih mudah diubah dibandingkan grafik 2, tetapi cukup sulit berubah dibandingkan grafik 1 .

Berbagai penelitian terdahulu juga telah memaparkan terkait kegunaan DISC untuk memetakan profil kepribadian seseorang. Seperti penelitian yang dilakukan oleh Rachmawati, Kusumastuti, dan Susanti (2016) tentang Pembelajaran Soft Skill Berbasis Pada Hasil Pemetaan Kepribadian Lulusan Universitas Widyatama Melalui Metode DISC (Dominance, Influence, Steadiness Dan Compliance). Penelitian ini memberikan gambaran terkait Profil Kepribadian Mahasiswa, sehingga memberikan arah karir yang jelas.

Selain itu, ada juga penelitian yang dilakukan oleh Mufida (2012) tentang Perbedaan Burn Out ditinjau Dari Gaya Kepribadian Dominance, Influence, Steadiness, dan Compliance. Hasil dari analisis data dalam penelitian tersebut menunjukkan bahwa terdapat perbedaan tingkat burn out saat dilakukan peninjauan dari gaya kepribadian $\mathrm{D}, \mathrm{I}, \mathrm{S}$ dan C. Artinya, responden dengan gaya kepribadian Dominance, Influence, dan Compliance memiliki tingkat burn out pada kriteria rendah, sedangkan responden dengan gaya kepribadian steadiness memiliki tingkat burn out sedang. 
Berdasarkan penelitian terdahulu, diketahui bahwa DISC sebagai salah satu alat tes psikologi dalam mengungkapkan profil kepribadian seorang individu, cukup efektif. Keefektivan penggunaan DISC, tentunya terlihat dari segi waktu yang terbilang cepat dalam mengungkapkan profil kepribadian seseorang. Hal inilah yang mendorong Peneliti untuk melakukan penelitian terkait pemetaan profil kepribadian calon karyawan dengan DISC untuk mengetahui pilihan karir calon karyawan dari PT. X Indonesia.

\section{METODE PENELITIAN}

Subjek dalam penelitian ini adalah para calon karyawan di PT. X Indonesia yang telah lolos seleksi berkas dan telah mengerjakan Psikotes khususnya Tes DISC. Jenis kelamin subjek yaitu perempuan dan laki-laki, dengan jumlah 211 subjek. Pengambilan subjek penelitian tidak secara acak, artinya semua kandidat yang mendaftar pada periode pengumpulan data memiliki kesempatan yang sama untuk menjadi subjek penelitian.

Metode penelitian yang digunakan yaitu survei dengan studi dokumentasi menggunakan data yang dimiliki oleh perusahaan. Metode pengumpulan data penelitian menggunakan alat ukur psikometri DISC yang telah distandarkan Indonesia atau Marston Model Indonesia (MMI), dan secara online diisi oleh subjek penelitian. Pengisian instrumen DISC yang digunakan untuk mengidentifikasi kepribadian subjek penelitian terdiri dari 24 nomor soal, yang masing-masing nomor soal terdiri dari 4 pernyataan. Subjek penelitian akan memilih 1 pernyataan yang paling menggambarkan dirinya dan 1 pernyataan yang paling tidak menggambarkan dirinya. Waktu pengerjaan tes DISC berdurasi 7 sampai 10 menit.

Data yang diperoleh kemudian diidentifikasi menggunakan aplikasi paten DISC atau software DISC yang digunakan oleh perusahaan PT. X Indonesia, kemudian peneliti melakukan olah data menggunakan Microsoft Office Excel 2013, sebagai analisa lanjutan untuk mengetahui keterkaitan antara Plihan Karir dan Profil Kepribadian DISC calon karyawan PT. X Indonesia.

\section{HASIL DAN PEMBAHASAN}

Penelitian ini bertujuan untuk mengidentifikasi pilihan-pilihan karir calon karyawan PT. X Indonesia yang ditinjau dari profil kepribadian dengan menggunakan alat tes DISC. Penelitian ini berlangsung selama kurang lebih 5 bulan. Berikut hasil dari penelitian ini:

\section{Karakteristik Demografi Subjek Penelitian}

Berikut disampaikan data terkait karakteristik subjek dalam penelitian ini, berdasarkan jenis kelamin dan pilihan pekerjaan karir yang dibutuhkan:

\section{Jenis Kelamin}

Berikut disampaikan data terkait distribusi frekuensi dan prosentase subjek berdasarkan jenis kelamin laki-laki dan perempuan dari 211 subjek:

\begin{tabular}{ccc} 
Tabel 1. Distribusi Berdasarkan Jenis & Kelamin \\
\hline Jenis Kelamin & Jumlah & $\%$ \\
\hline Laki-Laki & 125 & 59,24 \\
Perempuan & 86 & 40,76 \\
Total & 211 & $100 \%$ \\
\hline
\end{tabular}


Berdasarkan data diatas diketahui bahwa jumlah subjek penelitian yang berjenis kelamin laki-laki sebanyak 125 subjek atau 59,24\% dari subjek penelitian yang digunakan. Sedangkan subjek perempuan ada sebanyak 86 subjek atau $40,76 \%$ dari jumlah subjek penelitian. Oleh karena itu, total dari subjek penelitian yang ada berjumlah 211 subjek.

\section{Pilihan Karir}

Berikut disampaikan data terkait distribusi frekuensi dan prosentase subjek berdasarkan pilihan karir/ pekerjaan yang diinginkan dari 211 subjek:

Tabel 2. Distribusi Berdasarkan Pilihan Karir

\begin{tabular}{ccc}
\hline Pilihan Karir & Jumlah & $\%$ \\
\hline Account Manager & 3 & 1,42 \\
Admin & 4 & 1,90 \\
Branding and & 3 & 1,42 \\
Communication Manager & 17 & 8,06 \\
Bussiness Development & 2 & 0,95 \\
Chemist Assistant & 12 & 5,69 \\
Contact Center & 22 & 10,43 \\
Driver & 3 & 1,42 \\
Finance and Accounting & 10 & 4,74 \\
Graphic Designer & 5 & 2,37 \\
Human Resources & 50 & 14,22 \\
Operations & 10 & 4,74 \\
Office Boy & 5 & 2,37 \\
Online Sales Officer & 56 & 26,54 \\
Receptionist & 24 & 11,37 \\
Recruitment Staff & 3 & 1,42 \\
Sales Manager & 2 & 0,95 \\
Web Developer & 211 & $100 \%$ \\
Telemarketing & \\
Total &
\end{tabular}

Berdasarkan data diatas, diketahui bahwa ada 17 pilihan karir atau pekerjaan yang dilamar oleh sejumlah calon karyawan di PT. X Indonesia. Pilihan karir atau pekerjaan tersebut, sebenarnya belum sepenuhnya, karena di PT. X Indonesia sendiri, melayani permintaan kebutuhan karyawan dari perusahaan lain. Namun, 17 pekerjaan atau posisi inilah yang memiliki data lengkap dan dapat dilaporkan oleh peneliti sebagai data untuk diolah.

Dari data tersebut, diketahui ada 3 subjek yang melamar untuk posisi Account Manager atau sebesar 1,42\% dari 211 subjek. Posisi Admin ada 4 subjek atau 1,90\%. Posisi Branding and Communication Manager ada 3 subjek yang melamar atau 1,42\%. Posisi Bussiness Development ada 17 subjek yang melamar dari 211 subjek atau sebanyak 8,06\%. Posisi Chemist Assistant ada sebanyak 2 subjek atau 0,95\%. Contact Center ada 12 subjek yang melamar atau 5,69\%. Posisi Driver cukup banyak subjek yang dapat dianalisa yaitu sebanyak 22 subjek dengan prosentase $10,43 \%$.

Finance and Accounting ada 3 subjek atau 1,42\%. Posisi Graphic Designer ada 10 subjek atau 4,74\%. Human Resources Operations ada 5 subjek yang melamar atau sebanyak 2,37\%. Office Boy ada 30 subjek atau $14,22 \%$ yang dapat dianalisa datanya. Posisi Online Sales Officer sebanyak 10 subjek atau 4,74\%. Receptionist ada 5 subjek atau 2,37\% yang dapat diolah datanya. Sedangkan posisi Recruitment Staff cukup banyak subjek yang dapat dianalisa yaitu sebanyak 56 subjek atau 26,54\%. Posisi Sales Manager ada 24 subjek atau 11,37\%. Web Developer ada 3 subjek atau 1,42\%. Posisi Telemarketing ada 2 subjek atau 0,95\% dari 211 subjek yang dijadikan subjek penelitian.

\section{Karakteristik Kepribadian Subjek} Penelitian

Berikut disampaikan karakteristik kepribadian subjek penelitian, yang ditinjau dari profil DISC berdasarkan 
karakteristik calon karyawan secara umum yang melamar, jenis kelamin dan pilihan karir di PT. X Indonesia:

1. Keseluruhan Subjek Penelitian

Data berikut akan disampaikan terkait gambaran umum profil kepribadian dari keseluruhan subjek yang melamar di PT. X Indonesia:

Tabel 3. Gambaran Umum Profil Kepribadian Calon Karyawan

\begin{tabular}{ccc}
\hline $\begin{array}{c}\text { Profil } \\
\text { Kepribadian }\end{array}$ & Jumlah & $\%$ \\
\hline D & 15 & 7,11 \\
I & 13 & 6,16 \\
S & 92 & 43,60 \\
C & 91 & 43,13 \\
Total & 211 & $100 \%$ \\
\hline
\end{tabular}

Berdasarkan tabel diatas dapat dijabarkan bahwa calon karyawan yang memiliki tipe atau profil kepribadian dengan dominan tipe tipe D (Dominance) sebanyak 15 subjek atau 7,11\% dan dominan tipe I (Influence) sebanyak 13 subjek atau 6,16\%. Sedangkan calon karyawan yang memiliki tipe kepribadian dengan dominan S (Stadiness) sebanyak 92 subjek atau 43,60\%. Disusul oleh profil kepribadian C (Compliance) yaitu sebanyak 91 subjek atau 43,13\%. Oleh karena itu, dengan melihat data tersebut dapat disimpulkan bahwa secara umum calon karyawan PT. X Indonesia, didominasi oleh tipe atau profil kepribadian S (Stadiness).

\section{Jenis Kelamin}

Selain data gambaran umum profil kepribadian dari keseluruhan subjek, berikut juga disampaikan terkait profil kepribadian ditinjau dari jenis kelamin calon karyawan yang melamar di PT. X Indonesia:
Tabel 4. Profil Kepribadian Calon Karyawan Berdasar Jenis Kelamin

\begin{tabular}{ccccc}
\hline \multirow{2}{*}{$\begin{array}{c}\text { Profil } \\
\text { Kepribadian }\end{array}$} & \multicolumn{4}{c}{ Jenis Kelamin } \\
\cline { 2 - 5 } & \multicolumn{2}{c}{ Laki-Laki } & \multicolumn{2}{c}{ Perempuan } \\
\cline { 2 - 5 } & Jum & $\%$ & Jum & $\%$ \\
\hline D & 10 & 8,00 & 5 & 5,81 \\
I & 4 & 3,20 & 9 & 10,47 \\
S & 54 & 43,20 & 38 & 44,19 \\
C & 57 & 45,60 & 34 & 39,53 \\
Total & 125 & $100 \%$ & 86 & $100 \%$ \\
\hline
\end{tabular}

Berdasarkan data diatas, diketahui bahwa subjek berjenis kelamin laki-laki yang memiliki profil kepribadian dengan dominan tipe D (Dominance) sebanyak 10 subjek atau 8,00\%, dominan tipe I (Influence) sebanyak 4 subjek atau 3,20\%, dominan tipe S (Stadiness) sebanyak 54 subjek atau 43,20\%, dan calon karyawan dengan dominan tipe C (Compliance) yaitu sebanyak 57 subjek atau 45,60\%. Dapat disimpulkan bahwa calon karyawan yang berjenis kelamin laki-laki di PT. X Indonesia didominasi oleh tipe atau profil kepribadian C (Compliance).

Sedangkan calon karyawan PT. X Indonesia yang berjenis kelamin perempuan, didominasi oleh tipe atau profil kepribadian S (Stadiness). Berikut penjabarannya, subjek perempuan yang memiliki profil kepribadian dominan tipe D (Dominance) sebanyak 5 subjek atau $5,81 \%$, dominan tipe I (Influence) sebanyak 9 subjek atau 10,47\%, dominan tipe S (Stadiness) sebanyak 38 subjek atau $44,19 \%$, dan calon karyawan dengan dominan tipe C (Compliance) yaitu sebanyak 34 subjek atau 39,53\%.

Berdasarkan penelitian yang dilakukan oleh Alshehri, Alshamrani, Alharbi, Alshehri, Enani, Alghamdi, Alqulyti, Hassanien (2018), dengan subjek perempuan sebanyak 220 subjek (53\%) dan subjek laki-laki sebanyak 194 (47\%). Diketahui bahwa mayoritas subjek 
perempuan memiliki tipe kepribadian dominan C $(35,1 \%)$ dan minoritas memiliki tipe dominan I $(12,4 \%)$. Sama halnya dengan subjek yang berjenis kelamin laki-laki, yaitu mayoritas memiliki tipe kepribadian C $(36,4 \%)$ dan minoritas bertipe dominan I $(5,9 \%)$

Berdasarkan penelitian yang dilakukan oleh Kusumawati (Goni, Opod, \& David, 2016) bahwa perbedaan anatomi biologis dan hormon-hormon dalam tubuh dianggap berpengaruh pada perkembangan emosional dan kapasitas intelektual laki-laki dan perempuan. Selanjutnya, keadaan biologis yang dimiliki oleh laki-laki ataupun perempuan dapat mempengaruhi perilakunya dalam bertindak. Artinya, kondisi biologis atau hormon manusia memang cukup berpengaruh terhadap perilaku yang akan dimunculkan.

\section{Pilihan Karir}

Selain data gambaran umum profil kepribadian dari keseluruhan subjek dan profil kepribadian berdasarkan jenis kelamin, pada table 5 juga dipaparkan terkait profil kepribadian yang ditinjau dari pilihan karir atau jabatan atau lowongan pekerjaan yang dilamar oleh calon karyawan di PT. X Indonesia.

Tabel 5 menyajikan data terkait profil kepribadian yang ditinjau berdasarkan lamaran atau pilihan karir calon karyawan, didapatkan data bahwa ada 3 subjek yang melamar untuk posisi Account Manager, dan 100\% atau 3 subjek tersebut memiliki tipe kepribadian yang didominasi oleh tipe S (Stadiness). Artinya, tidak ada subjek atau calon karyawan yang memiliki tipe lainnya (D, I dan C), sehingga untuk posisi Account Manager didominasi oleh tipe kepribadian S.

Pada posisi Admin ada 4 subjek, dimana semua subjek tersebut 100\% memiliki tipe kepribadian $\mathrm{C}$ yang mendominasi individu-individu tersebut. Artinya, tipe kepribadian lainnya yaitu tipe D (Dominance), tipe I (Influence) dan tipe S (Stadiness) dari keempat subjek tersebut tidak ada yang memilikinya. Artinya, untuk posisi Admin didominasi oleh tipe kepribadian C. 
Tabel 5. Profil Kepribadian Calon Karyawan Berdasar Pilihan Karir

\begin{tabular}{|c|c|c|c|c|c|c|c|c|c|c|}
\hline \multirow{3}{*}{ Pilihan Karir } & \multicolumn{8}{|c|}{ Profil Kepribadian } & \multirow{2}{*}{\multicolumn{2}{|c|}{ Total }} \\
\hline & \multicolumn{2}{|r|}{$\mathrm{D}$} & \multicolumn{2}{|c|}{$\mathrm{I}$} & \multicolumn{2}{|c|}{$\mathrm{S}$} & \multicolumn{2}{|r|}{$\mathrm{C}$} & & \\
\hline & $\sum$ & $\%$ & $\sum$ & $\%$ & $\Sigma$ & $\%$ & $\Sigma$ & $\%$ & $\sum$ & $\%$ \\
\hline Account Manager & 0 & 0 & 0 & 0 & 3 & 100 & 0 & 0 & 3 & $100 \%$ \\
\hline Admin & 0 & 0 & 0 & 0 & 0 & 0 & 4 & 100 & 4 & $100 \%$ \\
\hline $\begin{array}{c}\text { Branding and } \\
\text { Communication Manager }\end{array}$ & 1 & 3,33 & 0 & 0 & 0 & 0 & 2 & 66,67 & 3 & $100 \%$ \\
\hline Bussiness Development & 0 & 0 & 1 & 5,88 & 7 & 41,18 & 9 & 52,94 & 17 & $100 \%$ \\
\hline Chemist Assistant & 1 & 50,00 & 0 & 0 & 0 & 0 & 1 & 50,00 & 2 & $100 \%$ \\
\hline Contact Center & 0 & 0 & 2 & 16,67 & 7 & 58,33 & 3 & 25,00 & 12 & $100 \%$ \\
\hline Driver & 0 & 0 & 0 & 0 & 16 & 72,73 & 6 & 27,27 & 22 & $100 \%$ \\
\hline Finance and Accounting & 0 & 0 & 0 & 0 & 0 & 0 & 3 & 100 & 3 & $100 \%$ \\
\hline Graphic Designer & 0 & 0 & 0 & 0 & 5 & 50,00 & 5 & 50,00 & 10 & $100 \%$ \\
\hline $\begin{array}{l}\text { Human Resources } \\
\text { Operations }\end{array}$ & 1 & 20,00 & 0 & 0 & 1 & 20,00 & 3 & 60,00 & 5 & $100 \%$ \\
\hline Office Boy & 0 & 0 & 0 & 0 & 13 & 43,33 & 17 & 56,67 & 30 & $100 \%$ \\
\hline Online Sales Officer & 2 & 20,00 & 0 & 0 & 6 & 60,00 & 2 & 20,00 & 10 & $100 \%$ \\
\hline Receptionist & 0 & 0 & 0 & 0 & 3 & 60,00 & 2 & 40,00 & 5 & $100 \%$ \\
\hline Recruitment Staff & 2 & 3,57 & 7 & 12,50 & 24 & 42,86 & 23 & 41,07 & 56 & $100 \%$ \\
\hline Sales Manager & 8 & 33,33 & 2 & 8,33 & 6 & 25,00 & 8 & 33,33 & 24 & $100 \%$ \\
\hline Web Developer & 0 & 0 & 1 & 33,33 & 0 & 0 & 2 & 66,67 & 3 & $100 \%$ \\
\hline Telemarketing & 0 & 0 & 0 & 0 & 1 & 50 & 1 & 50 & 2 & $100 \%$ \\
\hline
\end{tabular}

Posisi Branding and Communication Manager ada 3 subjek yang melamar. Dari data yang ada diketahui ada 1 subjek yang memiliki profil kepribadian dominan tipe D (Dominance) atau 3,33\%. Calon karyawan dengan dominan tipe $\mathrm{C}$ (Compliance) yaitu sebanyak 2 subjek atau $66,67 \%$ dari 3 subjek tersebut. Sedangkan untuk dominan tipe I (Influence) dan dominan tipe $\mathrm{S}$ (Stadiness), tidak ada subjek yang memiliki kecenderungan profil demikian. Artinya, untuk posisi Branding and Communication Manager didominasi oleh tipe kepribadian D dan C.
Posisi Bussiness Development ada 17 subjek yang melamar dari 211 subjek. Dari 17 subjek tersebut, tidak ada subjek yang memiliki profil kepribadian dominan tipe D (Dominance). Sedangkan untuk profil kepribadian dominan tipe I (Influence) sebanyak 1 subjek atau 5,88\%. Dominan tipe S (Stadiness) sebanyak 7 subjek atau 41,18\%. Selanjutnya calon karyawan dengan dominan tipe C (Compliance) yaitu sebanyak 9 subjek atau 52,94\%. Artinya, untuk posisi Bussiness Development didiminasi oleh tipe kepribadian S dan C. 
Posisi Chemist Assistant ada sebanyak 2 subjek dari 211 calon karyawan yang melamar. Dari data diketahui ada 1 subjek yang memiliki profil kepribadian dominan tipe D (Dominance) atau 50,00\%. Begitu juga dengan profil kepribadian dominan tipe $\mathrm{C}$ (Compliance) yaitu sebanyak 1 subjek atau $50,00 \%$. Sedangkan untuk profil kepribadian dengan dominan tipe I (Influence) dan tipe S (Stadiness) tidak subjek yang memiliki profil tersebut. Artinya, untuk posisi Chemist Assistant didominasi oleh tipe kepribadian D dan CPosisi Contact Center ada 12 subjek yang melamar. Dari data diketahui bahwa, untuk profil kepribadian dominan tipe D (Dominance) tidak subjek yang bertipe tersebut, dominan tipe I (Influence) ada sebanyak 2 subjek atau 16,67\%, dominan tipe S (Stadiness) sebanyak 7 subjek atau $58,33 \%$, dan calon karyawan dengan dominan tipe $\mathrm{C}$ (Compliance) yaitu sebanyak 3 subjek atau 25\%. Artinya, untuk posisi Contact Center didominasi oleh tipe kepribadian S.

Posisi Driver cukup banyak subjek yang dapat dianalisa yaitu sebanyak 22 subjek. Namun, untuk profil kepribadian dengan dominan tipe $\mathrm{D}$ (Dominance) maupun dominan tipe I (Influence), tidak ada subjek yang berprofil tersebut $(0 \%)$. Untuk profil kepribadian dominan tipe $S$ (Stadiness) ada sebanyak 16 subjek atau 72,73\%. Sedangkan calon karyawan dengan dominan tipe C (Compliance) yaitu sebanyak 6 subjek atau 27,27\%. Artinya, untuk posisi Driver didominasi oleh tipe kepribadian S.

Finance and Accounting ada 3 subjek yang dapat diolah datanya. Semua subjek sekitar 3 subjek atau 100\% memiliki tipe kepribadian yang dominan C (Compliance). Oleh karena itu, untuk profil kepribadian dominan tipe D (Dominance), dominan tipe I (Influence) dan dominan tipe S (Stadiness) tidak ada subjek yang berprofil demikian untuk posisi tersebut. Artinya, untuk posisi Finance and Accounting didominasi oleh tipe kepribadian $\mathrm{C}$.

Posisi Graphic Designer ada 10 subjek yang dapat diolah datanya. Dari 10 subjek tersebut, tidak ada subjek yang berprofil kepribadian dengan dominan tipe D (Dominance) maupun dominan tipe I (Influence). Sedangkan untuk profil kepribadian dominan tipe S (Stadiness) sebanyak 5 subjek atau 50\%. Begitu juga dengan tipe $\mathrm{C}$ (Compliance), memiliki distribusi subjek yang sama yaitu sebanyak 5 subjek atau 50\%. Artinya, untuk posisi Graphic Designer didominasi oleh tipe kepribadian S dan C.

Human Resources Operations ada 5 subjek yang melamar dan dapat diolah datanya. Dari data diketahui bahwa, profil kepribadian dominan tipe D (Dominance) ada sebanyak 1 subjek atau $20 \%$. Sedangkan untuk profil kepribadian dengan dominan tipe I (Influence), tidak ada subjek atau 0\%. Subjek dengan dominan tipe S (Stadiness) ada sebanyak 1 subjek atau 20\%. Calon karyawan dengan dominan tipe $\mathrm{C}$ (Compliance) yaitu sebanyak 3 subjek atau 60\%. Artinya, untuk posisi Human Resources Operations didominasi oleh tipe kepribadian $\mathrm{C}$.

Office Boy ada 30 subjek yang dapat diolah dan dianalisa datanya. Dari data diperoleh bahwa, distribusi subjek hanya ada pada tipe $\mathrm{S}$ dan $\mathrm{C}$, sedangkan tipe $\mathrm{D}$ dan I tidak ada subjek yang memiliki profil kepribadian dengan tipe tersebut. Berikut 
penjabarannya, subjek dengan profil kepribadian dominan tipe D (Dominance) dan dominan tipe I (Influence) sebanyak 0 subjek atau 0\%. Sedangkan subjek dengan dominan tipe S (Stadiness) sebanyak 13 subjek atau 43,133. Calon karyawan dengan dominan tipe C (Compliance) yaitu sebanyak 17 subjek atau 56,67\%. Artinya, untuk posisi Office Boy didominasi oleh tipe kepribadian $\mathrm{S}$ dan $\mathrm{C}$

Posisi Online Sales Officer sebanyak 10 subjek. Dengan distribusi sebagai berikut, subjek dengan profil kepribadian dominan tipe D (Dominance) sebanyak 2 subjek atau $20 \%$. Subjek dengan dominan tipe I (Influence) sebanyak 0 subjek atau $0 \%$. Subjek dominan tipe S (Stadiness) sebanyak 6 subjek atau 60\%. Subjek dengan dominan tipe C (Compliance) yaitu sebanyak 2 subjek atau 20\%. Artinya, untuk posisi Online Sales Officer didominasi oleh tipe kepribadian S.

Pada posisi Receptionist ada 5 subjek yang dapat diolah datanya. Distribusi subjek hanya ada pada profil kepribadian tipe S dan C. Sedangkan tidak ada subjek dengan profil kepribadian dominan tipe $\mathrm{D}$ (Dominance) maupun dominan tipe I (Influence) pada posisi ini. Subjek dengan profil kepribadian dominan tipe $S$ (Stadiness) sebanyak 3 subjek atau $60 \%$. Subjek dengan dominan tipe C (Compliance) yaitu sebanyak 2 subjek atau 40\%. Artinya, untuk posisi Receptionist didominasi oleh tipe kepribadian S dan C.

Sedangkan posisi Recruitment Staff cukup banyak subjek yang dapat dianalisa yaitu sebanyak 56 subjek, distribusi subjek terbanyak ada pada profil kepribadian dengan tipe S dan C. Dengan rincian sebagai berikut, ada sebanyak 2 subjek atau $3,57 \%$ yang berprofil kepribadian dominan tipe D (Dominance). Subjek dengan dominan tipe I (Influence) sebanyak 7 subjek atau 12,50\%. Sedangkan subjek dengan dominan tipe $S$ (Stadiness) sebanyak 24 subjek atau 42,86\%. Tidak jauh berbeda dengan subjek yang memiliki dominan tipe $\mathrm{C}$ (Compliance) yaitu sebanyak 23 subjek atau $41,07 \%$. Artinya, untuk posisi Recruitment Staff didominasi oleh tipe kepribadian S dan C.

Posisi Sales Manager ada 24 subjek yang dapat dioleh dan dianalisa. Subjek dengan profil kepribadian dominan tipe D (Dominance) ada sebanyak 8 subjek atau $33,33 \%$. Subjek dengan dominan tipe I (Influence) sebanyak 2 subjek atau 8,33\%. Subjek dengan dominan tipe $\mathrm{S}$ (Stadiness) sebanyak 6 subjek atau 25\%. Sedangkan calon karyawan dengan dominan tipe $\mathrm{C}$ (Compliance) yaitu sebanyak 8 subjek atau 33,33\%. Artinya, untuk posisi Sales Manager didominasi oleh tipe kepribadian D, S dan C.

Pada posisi Web Developer ada 3 subjek yang dapat diolah datanya. Rinciannya, tidak ada subjek dengan profil kepribadian dominan tipe D (Dominance) dan dominan tipe S (Stadiness) atau dapat dikatakan 0 dari 3 subjek yang ada. Sedangkan subjek dengan dominan tipe I (Influence) sebanyak 1 subjek atau $33,33 \%$. Calon karyawan dengan dominan tipe C (Compliance) yaitu sebanyak 2 subjek atau $66,67 \%$. Artinya, untuk posisi Web Developer didominasi oleh tipe kepribadian I dan $\mathrm{C}$.

Posisi Telemarketing ada 2 subjek dari 211 subjek yang dijadikan subjek penelitian. Hanya saja, untuk profil kepribadian dominan tipe D (Dominance) dan dominan tipe I (Influence), tidak ada 
distribusi sujek yang berprofil demikian. Sedangkan untuk subjek dominan tipe S (Stadiness) ada sebanyak 1 subjek atau $50 \%$. Begitu juga dengan profil kepribadian dominan tipe C (Compliance), ada sebanyak 1 subjek atau 50\%. Artinya, untuk posisi Telemarketing didominasi oleh tipe kepribadian S dan C.

Mufida (2012) menyampaikan bahwa tipe kepribadian satu dengan lainnya akan menghasilkan gaya kepribadian yang beda. Artinya, masingmasing gaya kepribadian DISC memiliki ciri khas yang berbeda. Ciri-ciri dari tipe kepribadian D (Dominance) yaitu pribadi individualis, efektif dalam bekerja, komunikasi cepat dan to the point, memiliki motivasi tinggi, percaya diri, bersemangat, penuh ambisi, ingin memimpin orang lain, kurang sabar, selektif, menyukai tantangan, visioner, agak ceroboh dan mandiri. Ciri-ciri dari tipe kepribadian I (Influence) yaitu persuasif, antusias, optimis, aktif berbicara, impulsif, emosional/ langsung bertindak, ramah, mencari posisi aman dalam segala hal, hangat dan bersahabat, mampu mnejadi penengah, senang bertemu banyak orang dan tampil, senang lingkungan kerja yang bebas dan minim pengontrolan, kurang disiplin, membesarkan masalah, dan ekspresif. Ciri-ciri tipe kepribadian S (Stadiness), yaitu pribadi yang stabil dan konsisten perilakunya serta juga menginginkan situasi yang demikian, terkendali, sabar, loyal, sulit beradaptasi, senang dengan situasi yang terkontrol dan prosedural, teguh, mengutamakan proses, objektif, pasif, santai dan menghindari tanggung jawab untuk memimpin orang lain terutama. Ciri-ciri kepribadian tipe C
(Compliance), yaitu pendiam, anti kritik, perfeksionis, detail, memiliki empati, rapi terorganisir, objektif, tekun dan disiplin, pesimis dan pemurung jika dalam tekanan, mampu mengontrol diri dan kurang ramah.

Menurut Sukardi (Savitri \& Muis, 2014), salah satu faktor yang mempengaruhi pemilihan karir seseorang adalah kepribadian, yang memiliki peranan untuk menentukan arah pilihan jabatan bagi seorang karyawan. Tampak bahwa pekerjaan yang didominasi oleh posisi manager misalnya Sales Manager dan Branding and Communication Manager, mayoritas memiliki profil kepribadian yang didominasi oleh tipe D (Dominance). Menurut Ososki (Alkhelil, 2016), seorang manager perlu memiliki keterampilan untuk mengelola orang maupun organisasi, sehingga dibutuhkan kemampuan analitik, kemampuan menjalin relasi dan kemampuan mengelola emosi.

Sedangkan bagi seorang pekerja teknis, dalam penelitian ini yaitu driver dan office boy, Menurut Ososki (Alkhelil, 2016) lebih mengutamakan keprofesionalitas mereka dibandingkan tingkat hirarki dalam organisasi. Artinya, pekerja teknis tersebut akan bekerja secara teliti, akurat dan mengikuti aturan serta butuh waktu menerima perubahan yang mendadak.

Sebagaimana hasil penelitian ini, menggambarkan bahwa tipe kepribadian mayoritas pada subjek yang berprofesi driver, office boy, telemarketing, bussinesse development adalah tipe dominan S dan C. Menurut Turnasella (Alshehri et al., 2018), orang dengan tipe kepribadian C diasumsikan sebagai pribadi yang pasif 
dan cenderung mengikuti aturan, serta nyaman dengan situasi yang stabil. Pribadi tersebut juga tergolong individu yang detail saat bekerja, serta mengutamakan kerapian.

\section{SIMPULAN}

Berdasarkan paparan yang ada, dapat disimpulkan bahwa sebagian besar subjek atau calon karyawan pada PT. X Indonesia, mayoritas memiliki profil kepribadian dengan tipe Steadiness (S) dan Compliance (C), baik pada subjek lakilai maupun perempuan. Selain itu, dari 17 pilihan karir atau pekerjaan yang dilamar, sebagian besar memiliki tipe kepribadian S dan C, terutama pada posisi staf. Sedangkan dari penelitian ini, ditemukan juga bahwa pada posisi manager, ada tipe kepribadian D (Dominance) yang juga menjadi tipe kepribadian yang mendominasi posisi tersebut.

Dari penelitian ini, ada beberapa saran yang dapat diberikan, baik bagi penelitian selanjutnya maupun bagi perusahaan, yaitu:

1. Bagi penelitian lanjutan, sebaiknya ditambah subjek penelitian, sehingga merata untuk penyebaran subjek. Karena dalam penelitian ini, ada beberapa pilihan karir atau pekerjaan yang jumlah subjek sedikit dan ada yang jumlah subjek tergolong banyak.

2. Bagi organisasi, sebaiknya untuk proses seleksi, dicocokan antara profil kepribadian dengan deskripsi jabatan yang diharapkan. Agar posisi jabatan yang dibuka dapat diisi dengan karyawan yang tepat, sesuai kepribadian dan potensi yang dimiliki.

\section{UCAPAN TERIMAKASIH}

Peneliti menyampaikan terimakasih yang mendalam kepada Fakultas Ekonomi dan Sosial Universitas Jenderal Achmad Yani Yogyakata, yang telah mendanai penelitian ini pada tahun 2019.

\section{DAFTAR PUSTAKA}

Alkhelil, A. H. (2016). The Relationship between Personality Traits and Career Choice: A Case Study of Secondary School Students. International Journal of Academic Research in Progressive Education and Development, 5(2). https://doi.org/10.6007/ijarped/v5i2/2132

Alshehri, K. A., Alshamrani, H. M., Alharbi, A. A., Alshehri, H. Z., Enani, M. Z., T. Alghamdi, M., Alqulyti, W. M., \& Hassanien, M. A. (2018). The relationship between personality type and the academic achievement of medical students in a Saudi medical school. International Journal of Community Medicine And Public Health, 5(8), 3205. https://doi.org/10.18203/23946040.ijcmph20183052

Anggit, I. (2019). Menteri Bappenas Sebut Produktivitas Tenaga Kerja RI Rendah. CNBC Indonesia. Diunduh Dari: https://www.cnbcindonesia.com/news/2 0190114142223-4-50542/menteri-

bappenas-sebut-produktivitas-tenagakerja-ri-rendah tanggal 1 Mei 2019.

Goni, C. K. E., Opod, H., \& David, L. (2016). Gambaran kepribadian berdasarkan tes Disc mahasiswa Fakultas Kedokteran Universitas Sam Ratulangi Manado semester 1 tahun 2016. Jurnal EBiomedik, 4(2). https://doi.org/10.35790/ebm.4.2.2016. 14686

Ismail, \& Nurjaya. (2016). Menggunakan Metode Wp ( Weighted Product) Dengan Bahasa. 1(1), 28-32.

Jemini-Gashi, L., \& Bërxulli, D. (2017). Personality Types, Career Choice and Career Certainty Among High School Students. International Journal of Teaching \& Education, V(1), 25-35. https://doi.org/10.20472/te.2017.5.1.00 
3

Makkl, S. (2019). Jumlah Pengangguran Februari 2019 Turun Jadi 6,82 Juta Orang. CNN Indonesia. Diunduh Dari: https://www.cnnindonesia.com/ekonomi /20190506124326-532-392272/jumlahpengangguran-februari-2019-turun-jadi682-juta-orang tanggal 1 Mei 2019.

Mufida, S. (2012). Perbedaan Burn Out ditinjau dari gaya Kepribadian Dominance, Influence, Steadiness, dan Compliance. Journal of Social and Industrial Psychology, 1(1), 34-40. http://journal.unnes.ac.id/sju/index.php /sip

Oasis Developing Center. (2014). DISC personality profile: comprehensive report. 1-17.

Rachmawati, R., Kusumastuti, D., \& Susanti, N. (2016). Pembelajaran Soft Skill Berbasis Pada Hasil Pemetaan Personality Lulusan Universitas Widyatama dengan Pendekatan Metode DISC (Dominance, Influence, Steadiness dan Compliance). Conference on Management and Behavioral Studies, 348-357.

Savitri, D., dan Muis, T. (2014). Key word: Survey of career choice, students. 04, 111.

Sulaeman, S. (2017). Ini Efeknya Jika Memaksa Bekerja Tidak Sesuai Passion. DetikHealth. Diunduh Dari: https://health.detik.com/beritadetikhealth/d-3549819/ini-efeknya-jikamemaksa-bekerja-tidak-sesuai-passion tanggal 1 Mei 2019.

Viatech Global. (2015). DISC Career Management.

Zamroni, E. (2016). Urgensi Career Decision Making Skills Dalam Penentuan Arah Peminatan Peserta Didik. Jurnal Konseling Gusjigang, 2(2), 140-152. https://doi.org/10.24176/jkg.v2i2.70o 